\title{
HENRI LEFEBVRE'S CONCEPT OF URBAN SPACE IN THE CONTEXT OF PREFERENCES OF THE CREATIVE CLASS IN A MODERN CITY
}

\author{
ADAM NADOLNY \\ Institute of Socio-Economic Geography and Spatial Management, Adam Mickiewicz University in Poznań, \\ Poland
}

Manuscript received: November 4, 2014

Revised version: April 14, 2015

\begin{abstract}
NADOLNY A., 2015. Henri Lefebvre's concept of urban space in the context of preferences of the creative class in a modern city. Quaestiones Geographicae 34(2), Bogucki Wydawnictwo Naukowe, Poznań, pp. 29-34. DOI 10.1515/ quageo-2015-0012, ISSN 0137-477X.

AвSTRACT: This article seeks to present how the manner of recording the spatial phenomena analysed by Henri Lefebvre in his numerous publications can serve as a basis for reflections on the suitability of his theories for the description of the creative class in a modern city. Because Lefebvre pursued a number of lines of thought in his philosophical ideas, we can state that there is a strong correlation between the city image he created and preferences of the creative class in a modern city. The article is also intended to make the reader realise that records of philosophical ideas can, in many instances, contribute to the improvement of the actual space in a city.
\end{abstract}

KEY WORDS: creative industries, creative class, philosophy, urban studies

Adam Nadolny, Institute of Socio-Economic Geography and Spatial Management, Adam Mickiewicz University, Dzięgielowa 27, 61-680 Poznań, Poland; e-mail: a.nadolny@amu.edu.pl

\section{Introduction}

The reflections comprised in this article will present how the creative output and lines of thought of Henri Lefebvre (1901-1991), a French philosopher, have shaped the phenomenon of a modern city in conjunction with the idea of urban space designated for the creative class. The issue of industrialisation takes up much of the philosopher's considerations, as in his view it has contributed to the degradation of the city seen as a complete work resulting from the efforts of the previous generations. Members of the creative class, due to their creative and professional efforts, can change the modern city image and facilitate the understanding of Lefebvre's idea of the city and its recreation.
Philosophical concepts intended to change modern urban space which share Henri Lefebvre's opinions and views perfectly match current trends in reflections on representatives of the creative sector of the economy. Any manifestations of creative activity in this area allow us to state that creativity is perceived not only in terms of knowledge; its inherent element is also the spatial behaviour pattern in the urbanised environment of a modern city.

\section{Henri Lefebvre's concept of a workplace and the creative class}

To reflect on the concept of a workplace in Henri Lefebvre's output, we should start with the 
knowledge of the past as a determinant of spatial activities. Lefebvre presented the theory of a workplace in his 1974 work entitled Production of space. Each place, or each urbanised space, should display a certain type of continuity resulting from the cycle of history and the time that creates this history. "A history of space would explain the development, and hence the temporal conditions, of those realities which some geographers call 'networks' and which are subordinated to the frameworks of politics. The history of space does not have to choose between 'processes' and 'structures', change and invariability, events and institutions. Its periodization, moreover, will differ from generally accepted ones. Naturally, the history of space should not be distanced in any way from the history of time" (Lefebvre 1991: 117-118).

Work-related activities that man undertakes are an important factor in the formation of space and spatial phenomena. Over the centuries human labour and man's involvement in its organisation have changed many times. The industrial revolution was a turning point in the history of mankind. On the one hand, due to the revolution and its steam machines, people could complete certain works in a shorter time, and on the other hand, due to urban development, the meaning of a workplace had been remodelled and undermined.

With the coming of the age of steam and fast development of society, man started to see dangers the city was exposed to due to human activity. What certainly contributed to the development of this area of study was the publication by Frederick Engels describing the situation of dwellers of industrial towns in England, The condition of the working class in England (London, 1845). His description of the distressing spatial conditions prevailing in industrial towns, the life of factory workers, and the urban horror strongly appealed to the imagination of architects, scientists and representatives of public life of those times.

The issue of industrialisation takes up much space in Henri Lefebvre's considerations, as in his view it had contributed to the degradation of the image of a city as a finished work produced by the work of generations. This line of reasoning led the philosopher to the sad conclusion that the paradigm of a modern city coined in the 20th century for the purposes of urban movements had contributed to new social divisions based on the structure of such a city ${ }^{1}$. The modern city differed much from the historical city, both in terms of scale and form.

At this stage of our reflections we should mention an Austrian architect Camillo Sitte (18431903), who was fascinated by the idea of a city perceived mainly in terms of public spaces. During his numerous travels across Europe, he would draw squares, streets and buildings which, in his opinion, had ideal proportions, a good shape and a human scale. In his works he gave examples of urban spaces created for people in such a way as to make them feel good. His examples came from antiquity, the Middle Ages and the Renaissance. The emphasis on the scale of urban space in which man is a key determinant shows these values to be deeply rooted in the culture of European cities. This manner of reasoning agrees with the concept of the city Lefebvre presents in his works.

The segregation of city inhabitants following from the modern system of the organisation of urban interiors and spaces has given many places, including streets, a new spatial expression significantly diverging from historical standards. Among the consequences of urban activities undertaken in many European countries after the Second World War were the depopulation of central districts of historic towns and the development of new housing districts for the middle class in the suburbs (Chiodelli 2013). The strength of local communities and the maintenance of relations among neighbours often used to be the driving force behind the development of a number of towns. The replacement of downtown dwellers with offices, banks and similar institutions caused shrinkage of those spaces in favour of suburbs.

\section{Henri Lefebvre's concept of 'the surplus of art' and the creative class}

The rise of revitalisation movements in the 1990s and the birth of the creative class ${ }^{2}$ have

Henri Lefebvre introduces the division of society into two basic groups. One stems from emotional interrelations among members of a community, the other from class divisions; they translate into the pattern of urban space.

2 The creative class is made up of scientists, engineers, architects, designers, i.e. all professions whose eco- 
changed the perception of urban space fundamentally. The basic idea guiding the creative class, namely voicing its expectations concerning the city and what it should offer as a spatial unit, perfectly matches the concept of space Lefebvre presented in his Production of space. He believed that space should display what might be called 'a surplus of art'. This is an indicator of the attractiveness of a city, and in particular of its centre with a concentration of high-quality spaces as seen in a town-planning perspective, accompanied by architectural facilities of great impact and aesthetic value. This type of a self-propelled double system of urban planning and architecture meets the assumptions posed by the philosopher in that representatives of the creative class, because of the nature of their work, can make use of different types of urban public space which, apart from the aforementioned spatial features, also have utility value: specialised stores, restaurants, etc.

This viewpoint of the philosopher goes well with reflections on the use of art as an indicator of space quality. To meet the expectations of the creative class, and with all types of interaction occurring in it, public space must be a multi-dimensional form. In conjunction with elements of art, architecture and urban planning, public space can significantly broaden the mind. In a way, it becomes an arena of new creative explorations, experiments or risk undertaken. The factors and types of interaction mentioned above widen the scope of spatial activities pursued by the creative class in the city.

\section{The concept of the materiality of space}

Lefebvre derived his reflections on labour as part of human existence from the theories propagated by Marx. Undoubtedly, he adjusted the definition of labour to his own expectations and to the trends of thought that appeared in Europe in the late 1960s and early '70s. One of the figures of speech which appears in the Production of space is the concept of the materiality of space. Space as a form displays characteristic elements by which it can be identified and analysed by its users.

In Lefebvre's interpretation, space can be identified by means of material elements such as

nomic function is to form new ideas. stone, wood, etc. Each of those elements is and has always been present in urban space in a number of forms. Without doubt, the ability to touch a stone sculpture or the possibility of sitting on a wooden bench is part of the process of the human perception of space. From the philosophical perspective, these elements become major components of the space transformation process; in this case, components of the great process called urbanisation. Thus defined, space is a place of spatial and social interactions. Human senses the sight, hearing, smell and taste, are other important factors in space identification (Simonsen 2005). Without the senses people would be deprived of the ability to perceive space, and this would render space completely useless.

The materiality of space and the possibility of its perception allow the conclusion that it is because of the materiality of space that people can sense its changeability or stability. As regards the creative class, this theory translated into the principle that, in order to define its self-awareness, it needs ever new external stimuli. The sensitivity inherent in the perception of space becomes an important point in creating a mental map each of the community members develops individually. Of course, space creation is not a solitary act, but an act of creation of the civil society, of each member thereof.

\section{Henri Lefebvre's 'urban citizen' as an element of the self-awareness of the creative class}

Pursuing this line of thought, representatives of the creative class in urban space could be classified as 'urban citizens'. The term, coined by Henri Lefebvre, refers to a social group which, because of social and cultural determinants, is best disposed to use the space. He sees an urban citizen as well suited to win in a number of spheres, like a representative of the creative class. Naturally winning also encompasses the use of all advantages offered by the modern city.

The nature of work performed by members of the creative class makes the urban community view them as a group and not as individual recipients of space. The natural fight to win is the driving force of many activities, so representatives of the target group, that is, urban citizens, 
have an opportunity to perform an active role in society. Their significant intellectual and financial competitive advantage translates into the creation of space meeting the expectations of the creative class. In many publications we can read that the creative class aspires to shape or build its daily and professional life on the basis of creative experiences (Florida 2002). On the other hand, according to Lefebvre's idea, 'urban citizens' are highly independent and self-reliant, and those are features typical of the creative class.

Summing up this part of our reflections, we must state that the ideas Henri Lefebvre presented in his Production of space correspond to the qualities in terms of which we define the creative class. On the one hand, labour as an element of creative self-awareness that translates into expectations concerning urban space; on the other, space itself, which should offer a wide range of experiences.

This search for new stimuli drives the interest of the creative users of urban space towards one of its basic organisational structures, namely the street. They are attracted by the local street culture with its variability, local colour, hustle and bustle, movement, and changes of perspective. Let us therefore pass on to the significance of the street in Lefebvre's reflections and its perception by the creative class.

\section{The street as a meeting space in Henri Lefebvre's reflections}

In his work of 1970, The urban revolution, Henri Lefebvre expresses some criticism of the fundamental element of the organisation of urban space, that is, the street. He comes up with the thesis that this space undergoes some degradation and deformation by its transformation into a consumer space. The flow of people in a city, including its streets, is determined by the number of shops they can visit. He suggests that the city is a spatial-temporal form where time spent on buying and selling equals the time bought and sold. This metaphor is to make us realise how difficult it is for urban space to co-exist in relation with the market economy and capitalism.

However, these reflections can also be interpreted in a different way. The consumptionism in space that Lefebvre criticises does not deprive space of its meaning or assets it has in the notion of urbanity. Taking into account the need for various types of spatial interactions, as mentioned above, such space becomes a good place for the existence of the creative class. Public space - here the street - is a key term for the understanding of the phenomenon of an environment dedicated to a group undertaking or participating in innovative activities.

Next, in his reflections on the street Henri Lefebvre puts forward the thesis about the colonisation of urbanised space by a variety of spatial phenomena connected with human activity which contribute to its appropriation. This contrasts with the standpoint maintaining that street space deprived of such human activities becomes a forgotten and quiet place in the urban fabric. On the other hand, this unique charm of oblivion and survival of certain spatial values attracts the interest of the creative class, whose members derive pleasure and fascination from exploring a space with particular cultural, social and spatial features. Oblivion, degradation or a fall of this type change into something positive that stimulates the development of one's imagination. The dominant feature of the creative class in urban space is a continuous acquisition of new skills which allow it to explore this space. Owing to this activity the space of a historic city can be rediscovered.

In The urban revolution references to the times past appear very frequently as if the past was an element bracing the modern discourse on the city. The past, in the opinion of the philosopher, is an important issue in reflections on the present. The historic town, with its wealth of experiences and an accumulation of spaces, is a perfect testing ground for exploratory activities of the creative class.

In his reflections Lefebvre tends to think that a modern city is in itself a new natural being created with the help of stone, glass and steel, but also such natural elements as the soil, air, wind, water and fire. This second nature he writes about is a twin space where opposing elements co-exist: light and darkness, water and stone, wood and metal, i.e. elements shaping the space of cities we live in. He shows vividly the image of a city which creates nothing by itself. To support the common opinion about the phenomenon of popular places in a city, he makes the radical state- 
ment that people who use the city - who live, trade, walk there - create it themselves, both at the mental and material levels. The city, he believes, serves only as a starting point triggering spatial situations which transform and create the diversity we need so much.

It is this diversity which makes the philosopher believe that the modern city is a form open to changes brought about by modern times, even if he is critical of its consumptionism. As far as expectations of the creative class are concerned, we can speak of the use of history as an element attracting the modern consumer of urban space. It must be emphasised that from the point of view of a person creating new 'products', public space, in this case the street and the historic town, will always be perceived as places providing an opportunity for broadening the mind, making new discoveries, or experimenting.

This type of human activity in space can also be defined as a form of gambling. We discover new places which stimulate us and change our viewpoint upon the surrounding reality, which we often perceive through the prism of the past.

In the street space of a historic town all class, generation or racial differences disappear. This is certainly value added which allows less formal and more spontaneous spatial interactions to arise. This type of human activity goes well with the main goals guiding Henri Lefebvre in his works. He attached great weight to the formation of space via everyday interactions, practising the space, or its appropriation and release to next users for temporary use. While street space belongs to all, it is also in a way a space that belongs to each of its users.

\section{Conclusions}

In this article I wanted to focus on relations between Lefebvre's philosophy and the space of a historic town in terms of ideas guiding the creative class. From the philosopher's point of view, the variety of sensual experiences this space offers is extensive and multifaceted, that is why this is what he explores in his writings. I only focused on a few selected aspects which, in my opinion, show a clear correlation between Lefebvre's ideas and the shape of the modern city perceived in terms of creativity. Even though his reflections date to the early 1970s, I think they are still inspiring.

In the first part of my article, I presented the concept of the workplace coined by Henri Lefebvre. It is crucial for my argumentation because it helps us to understand how labour as an element of human activity has contributed to the emergence of the idea of the creative class. The 'surplus of art' as a factor strongly correlated with a creative approach to life stimulates members of this class to use the resources of urban space even more extensively. Also the materiality of space is an important causative factor; without it, it would be impossible to shape space as a place of the already mentioned activities and interactions. Another element of this composition is the so-called urban citizen, who in my opinion is identical in his expectations and activities with a member of the creative class.

Finally, the article moved to one of the most important spatial urban elements, namely the street. In fact, the street was the starting point of the history of urbanism. Its shape and the accumulation of buildings and squares along its sides allows tracing the everlasting cycle of city formation, which is at present being rediscovered by members of the creative class.

The creative class is currently the subject matter of numerous publications analysing its impact on the phenomenon of urbanity and the perception of space, mainly urban space. Thanks to such an approach it has been possible to rediscover urbanity perceived through history correlated with human activity. To sum up, we must remember that owing to human activity, the city changes its face every day. This is a force that drives some cities to a better future, and others to collapse. Naturally, in this context we must not forget the creative class, which will always be the first to take a step towards the future.

\section{References}

Butler C., 2012. Henri Lefebvre: Spatial politics, everyday life and the right to the city. Routledge, New York.

Brenner N., Elden S., 2001. Henri Lefebvre in contexts: An introduction. Antipode: A Radical Journal of Geography 33(5): 764-768.

Chiodelli F., 2013. Planning and urban citizenship: Suggestions from the thoughts of Henri Lefebvre. Planning Perspectives 28(3): 487-494. 
Elden S., 2008. Understanding Henri Lefebvre: Theory and the possible. Continuum, London.

Florida R., 2002. The rise of the creative class. And how it's transforming work, leisure, community and everyday life. Basic Books, New York.

Kipler S., Saberi P., Wieditz T., 2012. Henri Lefebvre: Debates and controversies. Progress in Human Geography 37(1): 115-134.

Lefebvre H., 1991. Production of space. Blackwell, Oxford.

Lefebvre H., 1996. Writings on cities. Blackwell, Oxford.

Lefebvre, H., 2002. The critique of everyday life. Foundations for a sociology of the everyday. Verso, London.

Lefebvre H., 2003. The urban revolution. University of Minnesota Press, Minneapolis, London.
Marshall T., 1992. Citizenship and social class and other essays. Cambridge University Press, Cambridge.

Nadolny A., 2008. Christopher Alexander i Henri Lefebvre. Serce współczesnego miasta (Christopher Alexander's and Henri Lefebvre's heart of a modern city). Czasopismo Techniczne Z 3-A/2008: 265-271.

Simonsen K., 2005. Bodies, sensations, space and time: The contribution from Henri Lefebvre. Geografiska Annaler 87 B: 1-14.

Stanek L., 2011. Henri Lefebore on space: Architecture, urban research and the production of theory. University of Minnesota Press, Minneapolis. 